\title{
Za prof. Jozefom Klimkom
}

Koncom januára zastihla našu komunitu smutná správa o odchode prof. Jozefa Klimka vo veku 78 rokov († 24. 1. 2021). Jeho meno sa spája s mnohými profesionálnymi aktivitami. Okrem akademického pôsobenia je známe najmä jeho pôsobenie ako vel'vyslanca v Rakúsku po vzniku samostatnej Slovenskej republiky. Hoci obe susedné krajiny mali aj v tých časoch relatívne dobré vzt’ahy, jeho spomínanie na dynamické 90 . roky naznačovali, že nešlo len o výkon rutinnej diplomacie. Spätý bol aj s činnost'ou Paneurópskej vysokej školy (predtým Bratislavská vysoká škola práva), na ktorej pôsobil ako rektor a vedúci Ústavu teórie a dejín štátu a práva.

Hoci najvyššiu akademickú hodnost' dosiahol práve na

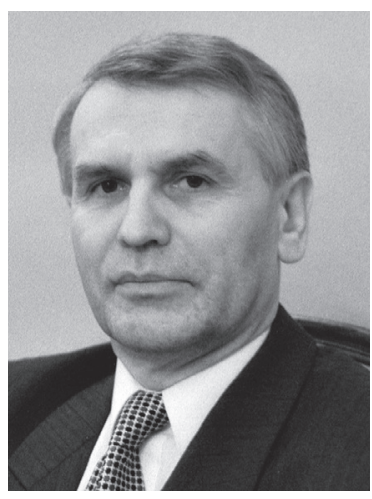
súkromnej vysokej škole, najdlhšie, v rokoch 1965-2009, pôsobil na Právnickej fakulte Univerzity Komenského. Stačí si len predstavit', že okrem obdobia Pražskej jari a následnej normalizácie bol svedkom obnovy akademickej samosprávy a následného vývoja po roku 1989. Po revolúcii takisto pôsobil vo funkcii prodekana pre vedecko-výskumnú činnost' a ako vedúci Katedry dejín štátu a práva. Bolo len prirodzené, že s takýmito bohatými skúsenost'ami pôsobil aj v redakčných radách najprestižnejších právnických vedeckých časopisov, ako Právny obzor, či Právněhistorické studie.

Z vedeckých a odborných aktivít treba u profesora Klimku spomenút' dva najdôležitejšie okruhy tém, ktoré $\mathrm{v}$ rámci svojho odborného zamerania spracovával. Tým prvým bol historický vývoj hraníc na území Slovenska, ktoré sa stali podkladom tak pre zisk titulu kandidáta vied, ako aj pre neskoršie habilitačné konanie. Mimoriadne prínosnou sa však stala jeho monografia Tretia ríša a ludácky režim na Slovensku (1986), ktorá bola z nášho pohl'adu azda jeho najvýnimočnejšou prácou. Dodnes sú cenné jeho analýzy vzt’ahov medzi nacistickým Nemeckom a ludáckym Slovenským štátom, charakteru oboch režimov i nerovnej pozície „farskej republiky“. Toto všetko profesor Klimko spracoval na základe svojho archívneho výskumu vo vtedajšom západnom Nemecku, ale aj na základe pramenného materiálu z vtedajšieho Štátneho ústredného archívu Slovenskej socialistickej republiky v Bratislave a z Archívu Ministerstva zahraničných vecí v Prahe. Všetky tieto výskumy, no nielen tie, ho predurčili k získaniu titulov profesor a doktor vied. Skúsenosti zo zahraničných pobytov, ale aj osobnostné vlohy ho potom nasmerovali k pracovným povinnostiam mimo Univerzitu Komenského. 
Na bratislavskú fakultu sa však ešte raz vrátil, a to na začiatku roku 2017, ked' doplnil rady Katedry právnych dejín a právnej komparatistiky. Jeho návrat na staré pracovisko bol návratom do výrazne mladého kolektívu, s ktorým sa postupne zoznamoval. Bolo logické, že sa stal prirodzenou autoritou a zásadne prispel k rastu katedry v tomto krátkom, sotva trojročnom období jej vývoja. Napriek krátkemu časovému úseku bolo jeho pôsobenie nenahraditel'né a význam jeho pracovných povinností prekračoval hranice katedry. Pracoval nielen ako oponent prác a člen mnohých komisií, najčastejšie v pozícii predsedu. Dá sa preto povedat', že profesor Klimko sa zúčastňoval, či priamo viedol inauguračné konania celej súčasnej generácie profesorov právnych dejín.

Bol tiež prítomný pri rôznych odborných prednáškach a konferenciách. Aj pri čisto neformálnych stretnutiach sme mali možnost' vypočut' si viaceré jeho trefné komentáre, hodnotenia, vystúpenia, či príhovory. Bývali ozdobou každého podujatia. Profesor Klimko bol známy predovšetkým úžasnou kombináciou formy a obsahu. Bolo l’ahostajné, ako vel'mi či málo formálne toto stretnutie bolo; či už išlo o inauguračné konanie, zasadnutie katedry alebo len „obyčajné“ predvianočné posedenie. Zakaždým dokázal atmosféru prostredia obohatit' svojou pamät’ou a skúsenost'ami. Mnohí si ho budú pamätat' ako človeka s originálnymi vyjadrovacími prostriedkami. Rozprával s gráciou, kvetnato a akiste každý dokázal ocenit' profesorovu schopnost' odhal'ovania tých lepších stránok na každom z nás.

Podl'a jedného úslovia je diplomatom ten, kto pozná presný dátum narodenia dámy, ale zabudol jej vek. Zdá sa, že toto profesora Klimka vystihovalo v jeho vzt'ahu k ostatným viac ako čokol’vek iné. A domnievame sa, že práve táto jeho - v najlepšom zmysle slova - starosvetská šarmantnost' sa najviac vryje do našej pamäte, ked' sa budeme spätne rozhliadat' a spomínat' na pána profesora. Bude nám všetkým chýbat'.

Miroslav Lysý, Róbert Brtko

doi: $10.14712 / 2464689 X .2021 .26$ 